\title{
Algal mats transport diaspores and carpological remains in shallow lakes
}

\author{
Artur Szymczyk
}

Received: 6 May 2015/ Accepted: 17 February 2016/Published online: 26 February 2016

(C) The Author(s) 2016. This article is published with open access at Springerlink.com

\begin{abstract}
Algal mats in lakes and reservoirs can transport diaspores and carpological remains of plants, and thus may influence the creation of taphocoenoses. In 2012, I quantified carpological remains in two types of algal mats from a small reservoir in southern Poland. Mats formed by filamentous algae participate primarily in the original transport of diaspores, and can influence their concentration and facilitate their migration, mainly between the shores of the reservoir. Diatom mats partake primarily in diaspore redeposition, but can also cause their dispersal between the shore zone and the central part of the reservoir. This research demonstrates that mats built by diatoms contain far more remains and are more biologically diverse than filamentous algal mats. Movement of carpological remains observed in both types of algal mats points to their role in the formation of taphocoenoses and suggests that algal mats must be considered when interpreting macrofossil records.
\end{abstract}

Keywords Algal mats - Aquatic vegetation . Carpological remains $\cdot$ Macrofossil analysis paleolimnology $\cdot$ Taphonomy

\footnotetext{
A. Szymczyk ( $\square)$

Department of Physical Geography, Faculty of Earth Sciences, University of Silesia, Będzińska Street 60, 41-200 Sosnowiec, Poland e-mail: artur.szymczyk@us.edu.pl
}

\section{Introduction}

Sediments that accumulate in lakes and peat bogs provide valuable records of past changes in aquatic environments (Tobolski 2000; Fabiańska et al. 2014). Analysis of plant macroremains is one of the most important and frequently used methods for inferring past environmental change (Dieffenbacher-Krall and Nurse 2005; Rasmussen and Anderson 2005; Birks 2007; Nita and Szymczyk 2010; Hrynowiecka and Szymczyk 2011). Increasingly, paleoecological methods are used to obtain valuable data for conservation and restoration of lacustrine ecosystems (Konieczna and Kowalewski 2009). Reconstructions of changes that occurred in phytocoenoses and in the environment, especially those that use analysis of macroscopic remains, including carpological remains, require knowledge of taphocoenosis formation (Szymczyk 2012), and of the complex relations between the macrofossil assemblage and contemporary vegetation (Zhao et al. 2006; Dieffenbacher-Krall 2007). Knowledge of the mechanisms that affect the distribution and abundance of remains in a reservoir is crucial for the interpretation of results.

Many complex factors affect the original transport of diaspores to their place of deposition and possible redeposition. However, a key factor that determines the distribution of seeds and fruits in a reservoir is their ability to float on the water surface (Birks 1973; Davis 1985; Szymczyk 2012). That ability and their dispersal over large distances enables many seeds and fruits, 
especially from rushes (Sculthorpe 1967) to occupy a diverse range of environmental conditions. Several adaptations promote widepsread dispersal, including the occurrence of aerenchyma tissue (Guppy 1906; Barrat-Segretain 1996), possession of a hydrophobic seed surface (Ridley 1930; van der Pijl 1969), and small mass (Müller-Schneider 1983; van der Pijl 1969), as is common in anemochorous species. Owing to these adaptations, some diaspores can float on the water surface for periods of weeks to several months (van den Broek et al. 2005). During that time, they can be tranpsorted by water currents or wind (Griffith and Forseth 2002; Boedeltje et al. 2003) over distances ranging from several to $>100 \mathrm{~km}$ (Andersson 2000). For many species, this ability enables them to spread across even the largest lakes. Anemochorous and zoochorous seeds also move long distances, the latter using fish or birds for transport (Green et al. 2002; Santamaria et al. 2002). Many seeds, however, especially those of water plants, float on the surface for a short time (Sculthorpe 1967; Johansson and Nilsson 1993) and tend to be deposited near the parent plant. Such seeds can move over large distances only with the aid of carriers or through redeposition.

Algal mats that amass periodically on the sediment surface and that later rise and drift on the water surface, can also transport and redeposit plant remains. Presence of algal mats on the surface of sediments is relatively common in both fresh (Wetzel 1996; Geddes 1997) and salt waters (Sundback et al. 1996). These mats can be composed of algae with filamentous thalli, diatoms, or cyanobacteria (Hillebrand 1983; Wetzel 1996). Their specific composition depends on the habitat preferences of the component species and they can be very diverse in reservoirs (Scheffer 2001). Many studies have shown that the species composition of algal mats can change seasonally in response to shifts in the availability of light, water temperature, and phosphorus, nitrogen and silica concentrations (Borchardt 1996; Goldsborough and Robinson 1996; McDougal et al. 1997; Anderson et al. 2004). In general, however, the formation of algal and cyanobacterial mats is determined primarily by periodic changes in trophic state (Rosenberg et al. 1990; Wetzel1996). Competition between macrophytes and microalgae for nutrients and light (Ozimek 1990; Scheffer 2001; Irfanullah and Moss 2005) means that shallow-water reservoirs and the littoral areas of large lakes with sediments only sparsely covered by macrophytes, are particularly suited for the formation of algal mats. The ecological preferences of algal species that dominate mats may cause proliferation to occur in reservoirs at different times. For example, in regions with a moderate climate, mats dominated by filamentous algae form no earlier than March (Wetzel 1996; Zohary et al. 1998). On the other hand, personal observations indicate that biofilms that form on sediments and are composed mainly of diatoms develop as soon as the ice melts. Regardless of their composition, all mats that form on the sediment surface or on aquatic plants, can be ripped from the substrate (Geddes 1997) and float to the water surface, where they drift and form rafts, as a result of gas bubbles that form during photosynthesis. Floating diatom mats carry a layer of the bottom sediments, enabled by their release of sticky, extracellular polymeric substances (Sutherland et al. 1998; Decho 2000), and therefore are capable of transporting diaspores they intercept on the water surface, as well as seeds and fruits lifted with the bottom sediments below.

The role of algal mats in the spread of diaspores in reservoirs and the creation of taphocoenoses has not been well studied. On the other hand, much research has been devoted to the conditions under which these mats form (Wetzel 1996; Zohary et al. 1998; Berry and Lembi 2000), their function in ecosystems (Hillebrand 1983; Usher and Blinn 1990; Falkowski and Raven 2007), and their role in the stabilization and prevention of sediment resuspension, and the cycling of phosphorus, nitrogen and carbon (Ozimek 1990; Goldsborough and Robinson 1996; McDougal et al. 1997; Scheffer 2001; Frost and Elser 2002; Widdows et al. 2004; Irfanullah and Moss 2005). Given the conditions that facilitate formation of algal mats, it is reasonable to assume that floating algal rafts played an important role in the early development of many lake ecosystems. This could be true especially for lakes at an early stage of evolution when they had little macrophyte biomass, but sufficient light penetration to support plant growth.

This study was undertaken to examine whether algal mats that form in reservoirs transport diaspores and carpological remains of plants, especially between the littoral zone and the central part of the reservoir, and thus affect taphocoenoses formation. At the same time, I conducted an assessment of the scale of diaspore and carpological transport for the different 
ecological groups of plants that grow in the reservoir and its immediate surrounding.

Study site

Although algal mat formation is common, it does not occur in all reservoirs. It is even less commonplace to observe biofilms built by diatoms, and mats created mainly by filamentous algae, in the same reservoir. I, however, selected for study a small reservoir in southern Poland (Fig. 1), in which both types of algal mats were observed regularly. Floating mats of filamentous algae can be observed even in late summer, when fruits begin to ripen and most plants in hydrogenic habitats disperse seeds. The study system is a small reservoir ( $0.45 \mathrm{ha})$ that was created in the 1950 s by flooding of an excavated sand pit located in the upper section of a valley. The reservoir does not have a control dam and thus has a stable water level. It is supplied by stream input and is connected by a small isthmus, which is vegetated by rushes, to another small reservoir at higher elevation. The maximum depth of the study reservoir is $\sim 2.5 \mathrm{~m}$. Almost $40 \%$ of the basin consists of shoals with depths up to $0.5 \mathrm{~m}$ (Fig. 1), which are sparsely vegetated or barren. High water transparency makes these shoals ideal locations for periodic development of biofilm sediments, built by diatoms, and growth of filamentous algae. The reservoir is surrounded by forests composed of multiple plant species (Fig. 1). The northern part of the drainage basin is quite steep and sandy shores have enabled development of small patches of grassland plants, which also grow along paths near small bays. A small part of the embankment
Fig. 1 Location and bathymetric map of study reservoir

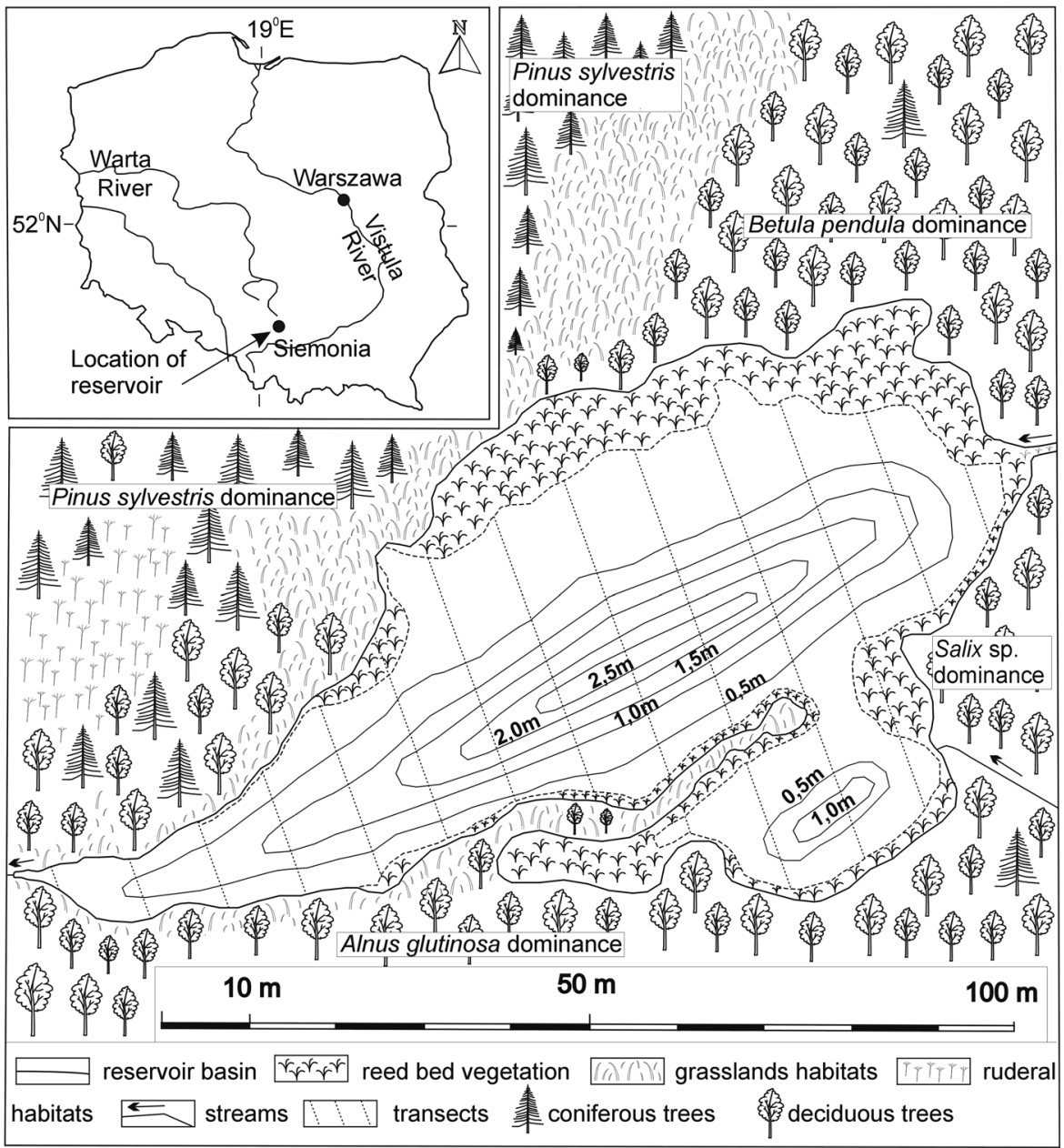


in the littoral area is also vegetated by ruderal plants. The aquatic vegetation is represented by 10 species. Vegetation patches occupy about $40 \%$ of the reservoir area. Rush stands are quite well developed, especially in the eastern part of the lake, and carpological remains of the species there are frequently found in Holocene and Pleistocene lake sediments.

\section{Materials and methods}

The study of plant community composition, diversity and distribution in the reservoir was conducted in August 2012. Species were assigned to four groups related to habitat type: (1) stoneworts, submerged plants and plants with floating leaves; (2) rush plants and those related to rush phytocoenoses; (3) plants from terrestral habitats in the reservoir basin; and (4) trees and shrubs. A pontoon boat was used to sample the reservoir. Transects were designated to assess the general abundance of plant species in the reservoir. To assess the abundance of macrophytes, the DAFOR (dominant, abundant, frequent, occasional, rare) fivedegree scale was used (Palmer et al. 1992). At the same time, a floristic list was made. While study of the vegetation along the transects was conducted, a survey of water depths was also made, which enabled the production of a bathymetric map of the reservoir.

Samples of algal mats were collected from the water surface during periods of peak occurrence using a sieve with $0.2-\mathrm{mm}$ mesh. Mats built mostly by diatoms were collected in late April and early May 2012, whereas samples of mats formed primarily by filamentous algae were collected in mid-September 2012. In total, 60 samples of algal mats were collected, each of which was $400 \mathrm{~cm}^{2}$ in size. Thirty of the collected samples were mats formed primarily by filamentous algae, whereas the other 30 samples were formed predominantly by diatoms.

To separate diaspores from the sediment, fresh samples from mats formed by diatoms were rinsed using a sieve with 0.2-mm mesh. Carpological remains were separated using a stereoscopic microscope. During identification of the remains, specialized keys and atlases were used (Berggren 1969; Cappers et al. 2006). Identification was also supported by a collection of comparative samples that had been assembled previously. I was unable to classify some carpological remains to species level. This applied to seeds of genera such as Typha, Juncus, Epilobium, Mentha, Salix and of the family Poaceae, whose identification to the species level is difficult.

To determine the relationship between contemporary vegetation and its representation in the assemblage of remains in algal mats, the percentage of contemporary species represented in the macroremains assemblage was calculated. This percentage was calculated in relation to the number of all currently occurring species, without regard to the ease of identification of their carpological remains. The diversity index $\left[\mathrm{H}^{\prime}\right]$ for remains and diaspores transported in algal mats was calculated using the ShannonWiener Index (Shannon and Weaver 1949), defined as: $\mathrm{H}^{\prime}=-\Sigma$ pi ln pi, where "pi" is the proportion of the assemblage made up of diaspores or remains of the ith species in the sample. Then, descriptive statistics and statistical inference were used, using the formulas and methods of Sobczyk (1994) and Kończak and Trzpiot (2002) to compare species diversity of remains in both types of mats. In terms of descriptive statistics, the following measures were used: the arithmetic mean $[\bar{x}]$, standard deviation, coefficient of variation $\left[V_{z}\right]$ and range area $[R]$. Statistical inference tests were used to evaluate the difference between means in the two populations, assuming that the variances were unequal. I applied the Student's T-distribution, using the formula proposed by Sobczyk (1994).

\section{Results}

One-hundred-and-twenty-seven plant taxa were identified in the reservoir and the area immediately surrounding it. The surrounding mixed-species forest is dominated by Betula pendula Roth. The small patches of grassland and ruderal vegetation near the reservoir led to recovery of remains of several terrestral species. All grass species, along with the genera Cirsium and Geranium, made these the most numerous group of plants, totalling 49 species (Table 1). The belt of rush plants, well developed particularly in the western part of the reservoir, is composed mainly of Phragmites australis (Cav.) Trin ex. Steudel, Carex rostrata Stokes, C. acutiformis L. and Sparganium erectum L. em. Rchb. Deeper sites near the shores are also vegetated by extensive patches of Sparganium emersum Rehmann. Beyond the reservoir, along the shores of the stream that supplies it and 


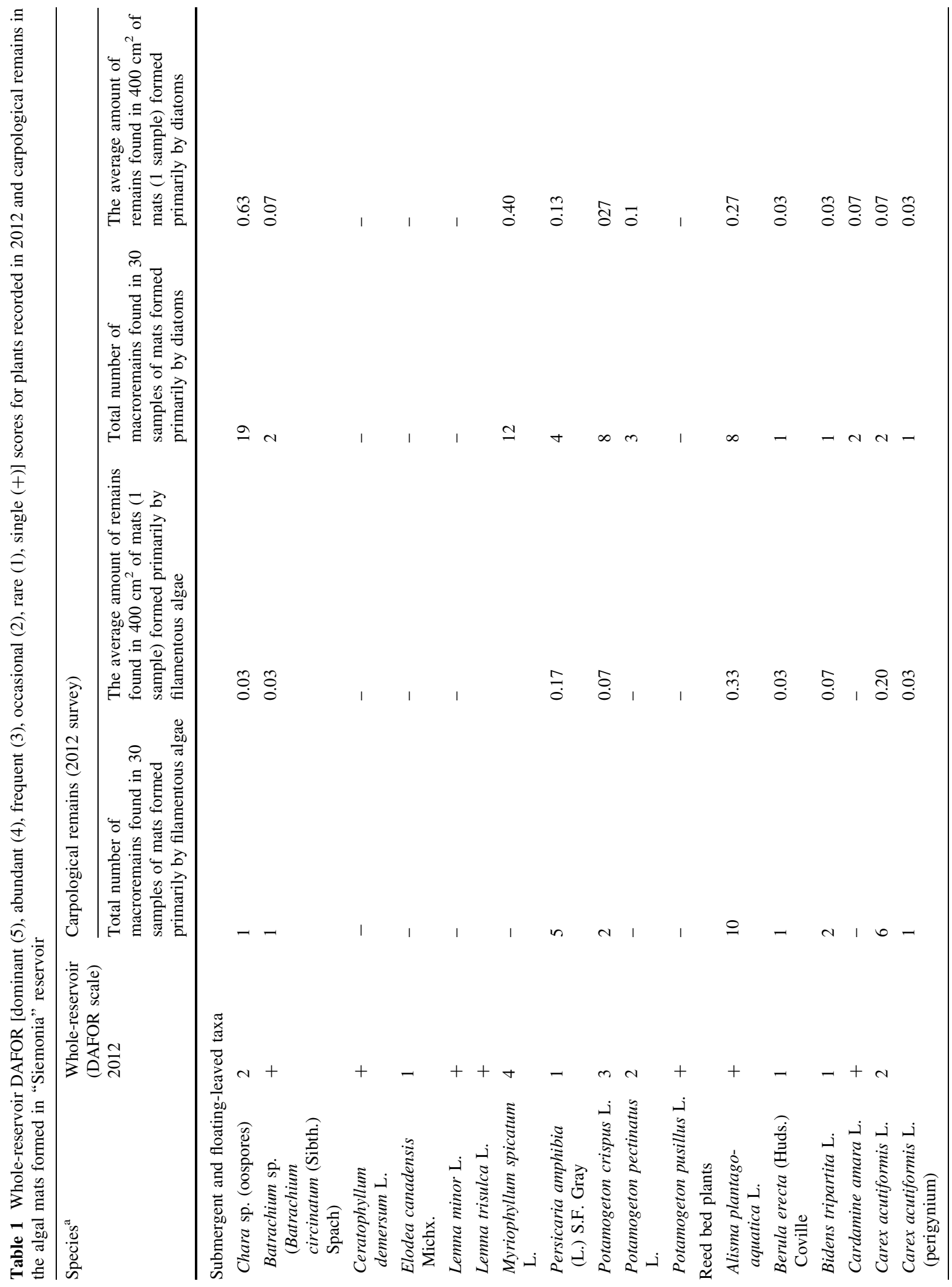




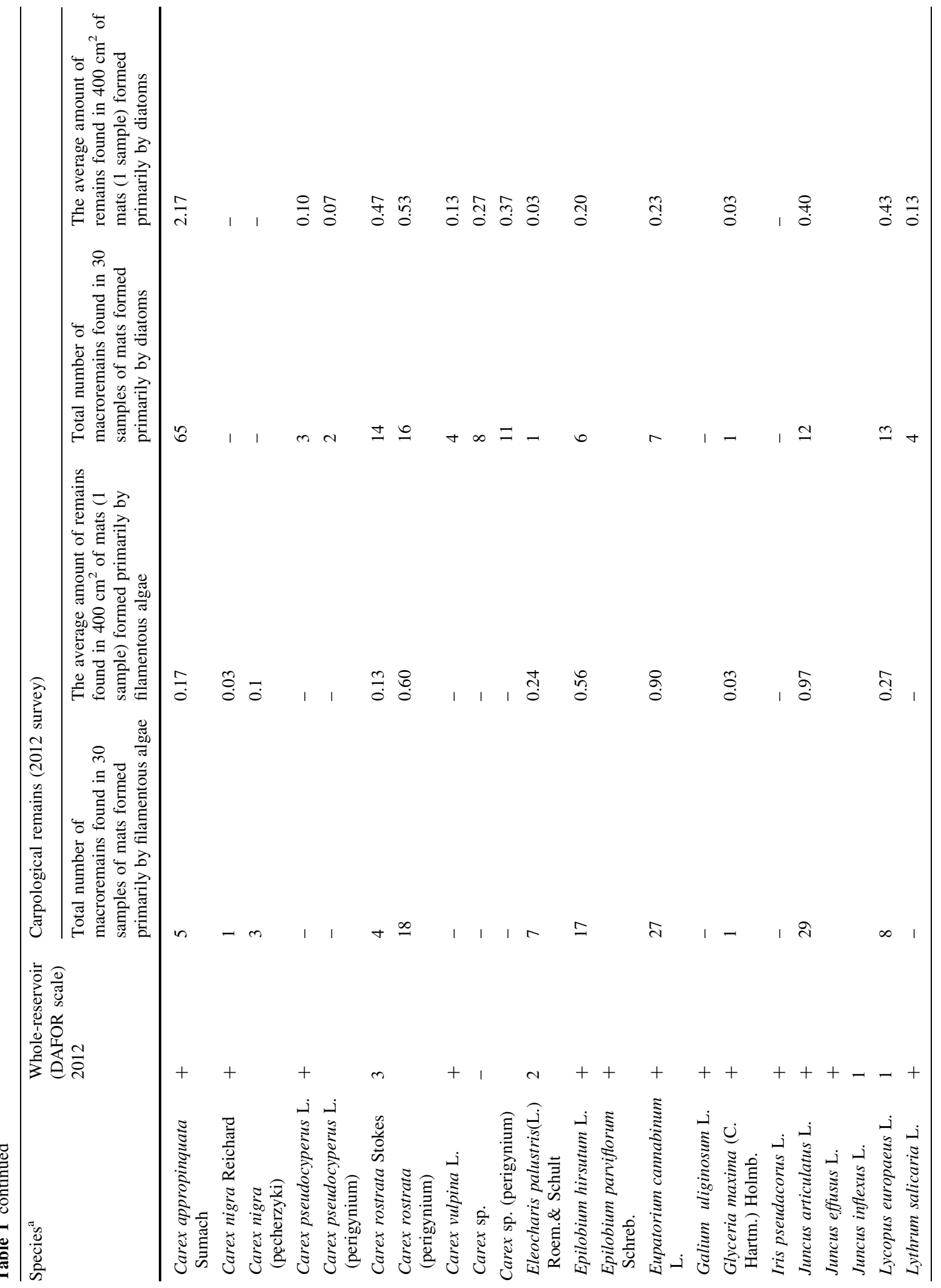




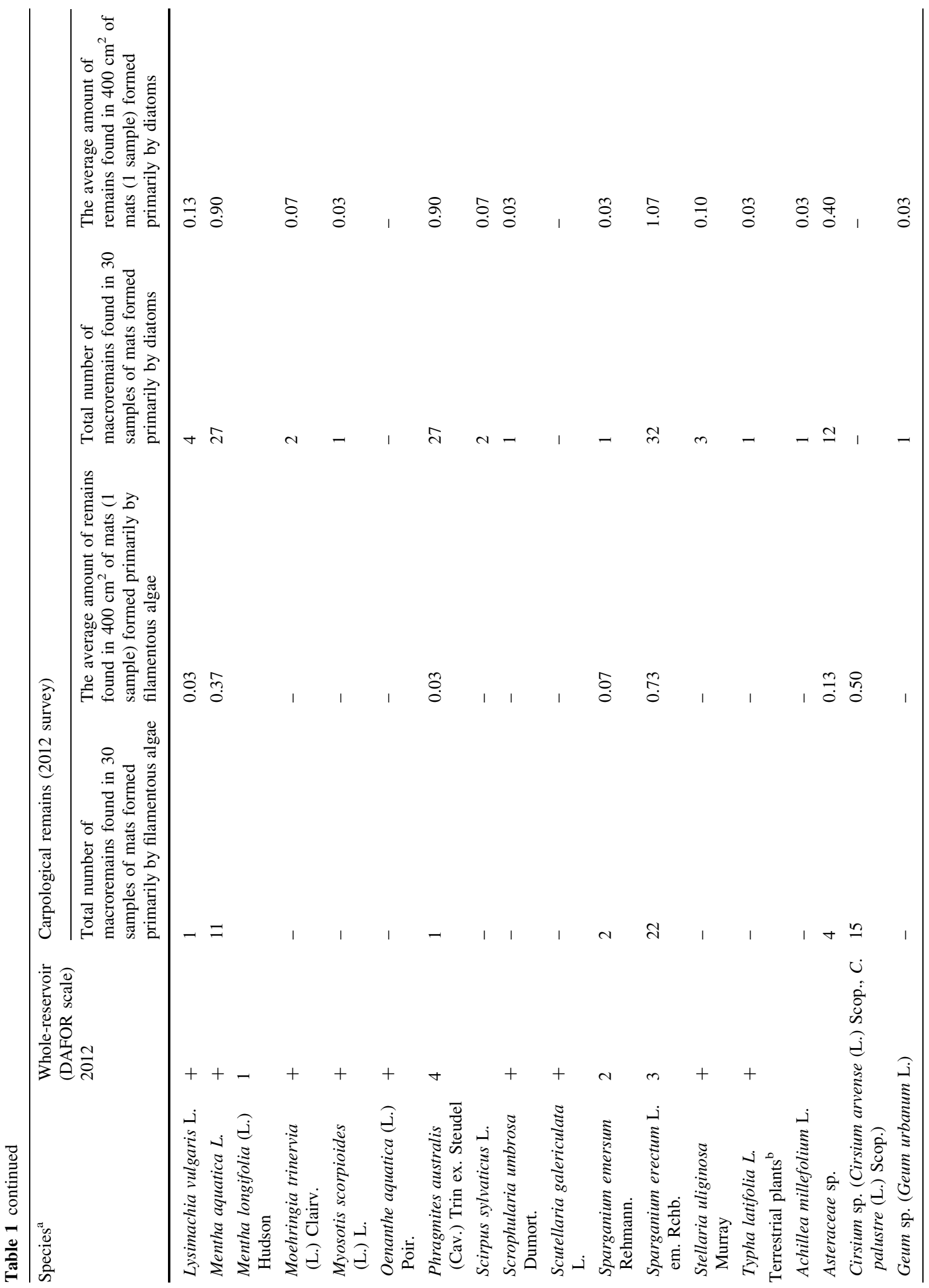




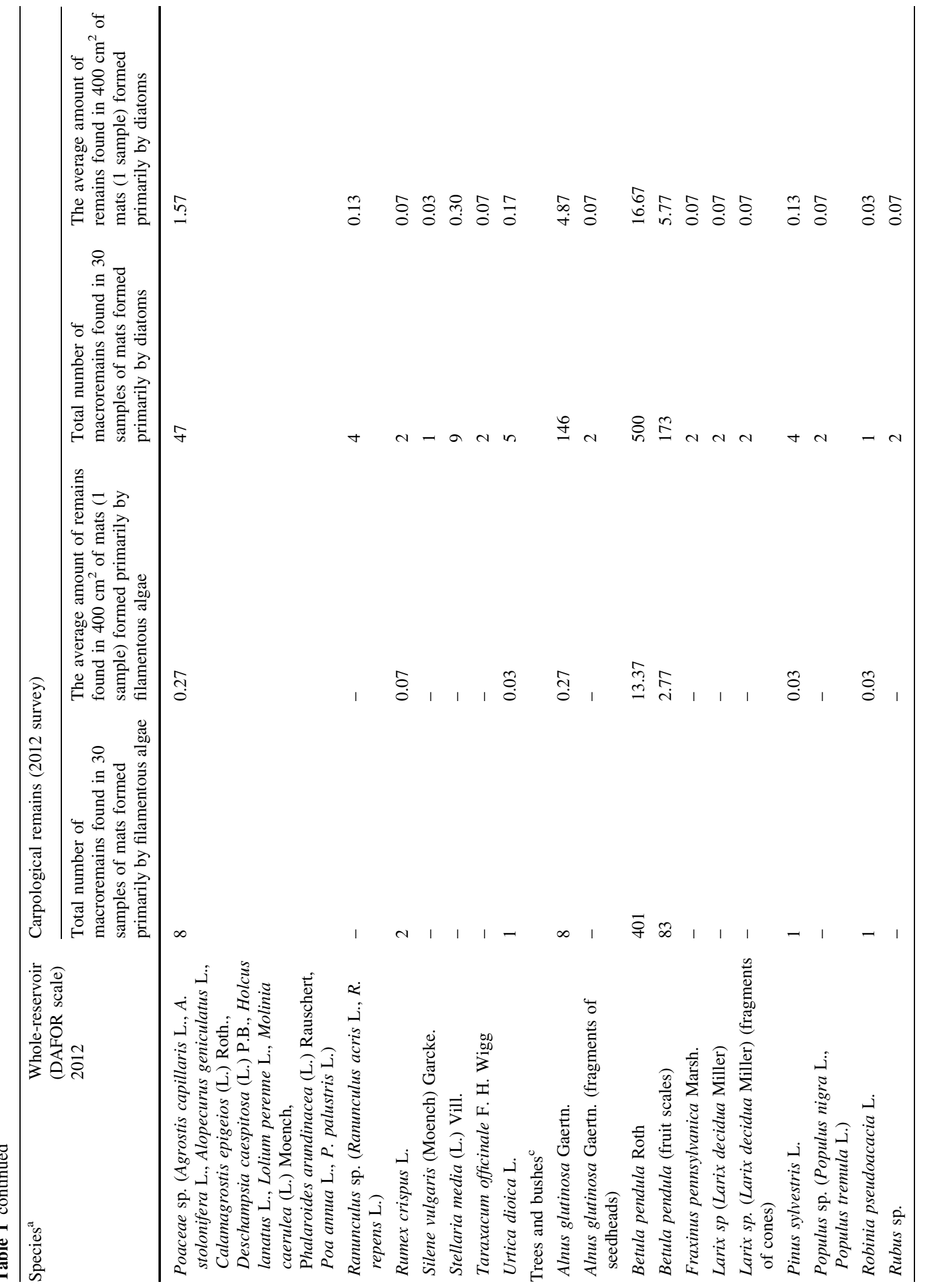




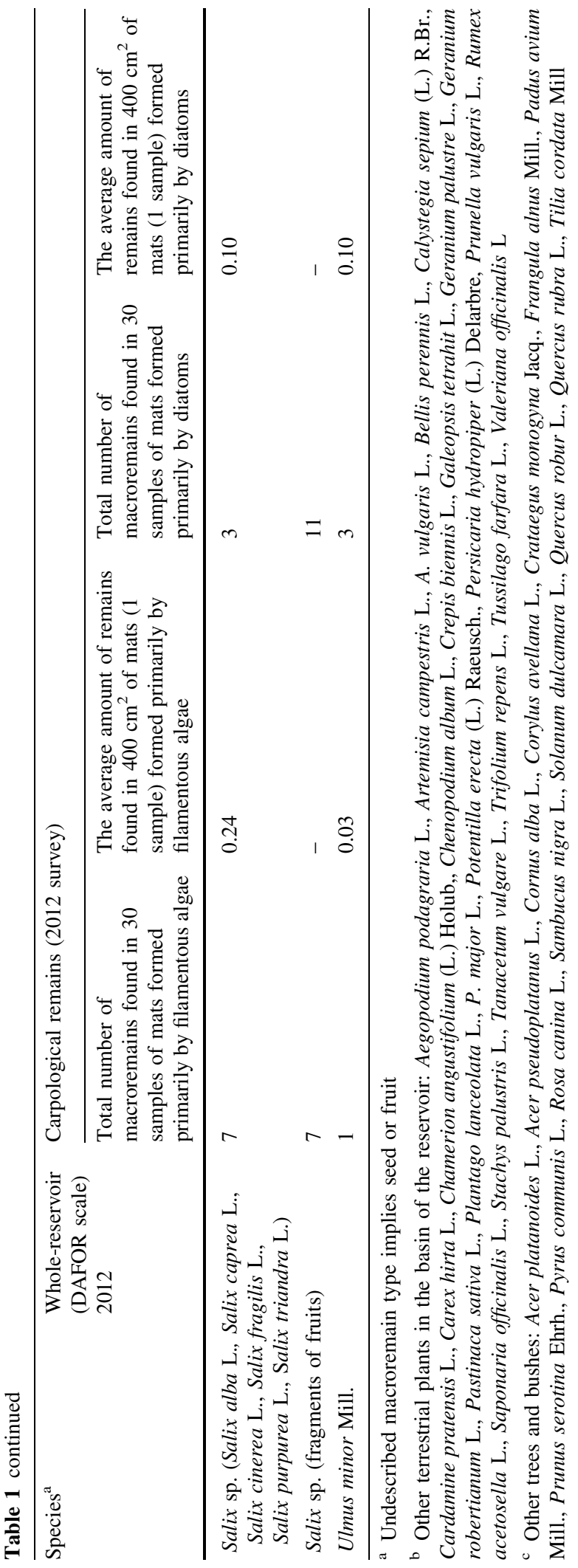


in the narrow, vegetated isthmus connecting the lake to the reservoir situated to the east, there are numerous hursts of Carex appropinquata Sumach. Among the species that frequently accompany rush vegetation were Bidens tripartita L., Lycopus europaeus L., Mentha longifolia (L.) Hudson and Juncus inflexus L. In the water, the most extensive phytocoenoses are formed by Myriophyllum spicatum L. and Potamogeton crispus L. Smaller beds of submerged vegetation are formed, in the shallower places, by Potamogeton pectinatus L. and Chara sp. (Table 1). In the samples of both types of algal mats, 1992 carpological remains belonging to 54 taxa of vascular plants and oospores of the non-vascular Chara spp. were identified (Table 1). They represent $43.3 \%$ of the samples of species that currently grow in the reservoir and its immediate vicinity (Table 2). Mats built primarily by diatoms had more carpological remains, in terms of both amount and species diversity (Table 2). The macroremains found in samples taken from both types of algal mats were dominated by Betula pendula fruits (Table 1), which comprise $58.1 \%$ of all enumerated remains. The best represented groups in the assemblages of carpological remains from algal mats were a group of rush- and rush-belt-related plants, and a group of aquatic plants (Table 2). Considering all ecological groups of plants, the algal mats formed primarily by diatoms demonstrated a better representation of contemporary vegetation (Table 2 ).

The average value of the Shannon index $\left[\mathrm{H}^{\prime}\right]$ for remains in the filamentous mats was significantly lower than that for diatomaceous mats. Values for individual samples of both types of mats, however, are similar. Lowest values for filamentous mats were significantly lower than those for diatomaceous mats (Table 3). Differences between the two groups of samples, seen in variations of the typical range area [R] and the coefficient of variation, $V_{z}$, indicate

Table 3 Selected measures of descriptive statistics for the Shannon-Wiener index $\left[\mathrm{H}^{\prime}\right]$ applied to samples from filamentous algae and diatom mats

\begin{tabular}{lll}
\hline $\begin{array}{l}\text { Measures of } \\
\text { descriptive statistics }\end{array}$ & $\begin{array}{l}\text { Samples of } \\
\text { filamentous mats }\end{array}$ & $\begin{array}{l}\text { Samples of } \\
\text { diatomaceous mats }\end{array}$ \\
\hline Average $[\bar{x}]$ & 1.19 & 1.83 \\
Maximum & 2.30 & 2.64 \\
Minimum & 0.19 & 1.33 \\
Coefficient of & 0.47 & 0.20 \\
$\quad$ variation $\left[\mathrm{V}_{\mathrm{Z}}\right]$ & & $1.47-2.20$ \\
$\begin{array}{l}\text { Typical range area } \\
\quad[\mathrm{R}]\end{array}$ & $0.63-1.75$ & 0.37 \\
$\begin{array}{l}\text { Standard deviation } \\
{\left[\mathrm{S}_{(\mathrm{X})}\right]}\end{array}$ & 0.56 & \\
\hline
\end{tabular}

Table 2 Representation of ecological groups of plants in assemblages of carpological remains found in algal mats of "Siemonia" reservoir

\begin{tabular}{|c|c|c|c|c|}
\hline \multirow{2}{*}{$\begin{array}{l}\text { Ecological } \\
\text { groups }\end{array}$} & \multicolumn{2}{|c|}{ Algal mats formed primarily by filamentous algae } & \multicolumn{2}{|c|}{ Algal mats formed primarily by diatoms } \\
\hline & $\begin{array}{l}\text { The number of taxa } \\
\text { represented in the } \\
\text { assemblages of } \\
\text { macroremains }\end{array}$ & $\begin{array}{l}\text { The percentage of } \\
\text { contemporarily occurring } \\
\text { species represented in the } \\
\text { assemblages of macroremains } \\
(\%)\end{array}$ & $\begin{array}{l}\text { The number of taxa } \\
\text { represented in the } \\
\text { assemblages of } \\
\text { macroremains }\end{array}$ & $\begin{array}{l}\text { The percentage of } \\
\text { contemporarily occurring } \\
\text { species represented in the } \\
\text { assemblages of macroremains } \\
(\%)\end{array}$ \\
\hline $\begin{array}{l}\text { Submergent and } \\
\text { floating-leaved } \\
\text { taxa }\end{array}$ & 4 & 36.4 & 6 & 54.5 \\
\hline Reed bed plants & 18 & 50.0 & 27 & 75.0 \\
\hline $\begin{array}{c}\text { Trees and } \\
\text { bushes }\end{array}$ & 6 & 19.4 & 10 & 32.3 \\
\hline $\begin{array}{l}\text { Terrestrial plants } \\
\text { in the basin of } \\
\text { the reservoir }\end{array}$ & 5 & 10.2 & 10 & 20.4 \\
\hline $\begin{array}{l}\text { In total, all the } \\
\text { ecological } \\
\text { groups }\end{array}$ & 33 & 26.0 & 53 & 41.7 \\
\hline
\end{tabular}


greater within-group heterogeneity in $\mathrm{H}^{\prime}$ values of filamentous mat samples (Table 3).

\section{Discussion}

Research on mechanisms responsible for transport of plant seeds and fruits from hydrogenic habitats, especially between the littoral zone and the central part of the water body, are important for understanding ecology of plants, and to shed light on the formation of taphocoenoses, a process that is critical for paleobotanical and paleolimnological interpretation. Clarifying the role of algal mats in this transport is important, because they form in an array of aquatic ecosystems. Algal mats may be dominated by different algal species and cyanobacteria (Hillebrand 1983; Wetzel 1996), with very different habitat requirements (Scheffer 2001). Results of this research indicate that mats built by filamentous algae and diatoms can affect the transport of diaspores and their remains within a reservoir. In many cases one can assume that such mats played a role in the transport and formation of macroremain assemblages in the past. Evidence for the existence of conditions conducive to formation of algal mats, and their impact on the transport of diaspores and other remains, can be obtained from study of sediments. Formation of algal mats in shallow reservoirs or bays is promoted by certain conditions such as high nutrient concentrations, in combination with high water transparency maintained by abundant submerged macrophytes. Nevertheless, both types of mats tend to grow in areas unoccupied by or poorly vegetated by submerged plants, perhaps testimony to the competition between algae and macrophytes seen in other shallow water bodies (Wetzel 1996; Kornijów and Halkiewicz 2007).

The importance of both types of algal mats for the transport of diaspores and their remains is indicated by their high concentration in collected samples with an area of $1.2 \mathrm{~m}^{2}$, by the large percentage of modern species represented in the macroremain assemblages, and by high values of the Shannon diversity index (Table 3). As many as 725 diaspores from 33 taxa were found in samples from the filamentous mats, with an average of 24.2 diaspores per sample. In the mats built by diatoms, the number of diaspores, representing 53 taxa, was larger by $74.8 \%$, with an average of 42.2 diaspores per sample (Table 2). The generally high proportion of aqueous species represented in macroremain assemblages from the algal mats (Table 2) (36.4\% in filamentous mats and $54.5 \%$ in diatomaceous mats), is comparable to values obtained from surface sediment layers in similar small water bodies. Examples include Lakes Juusa and Viitna, in which the sediments contained the remains of $50 \%$ of the extant aquatic plants (Koff and Vandel 2008), Groby Pool: $40 \%$ (Davidson et al. 2005) and Lake Sławków: 60 \% (Szymczyk 2012).

The common characteristic of both types of mats, essential for the transport of diaspores and their remains, is the ability to rise to the surface and drift across the lake, a consequence of trapped gas bubbles. Differences between the two mat types arise because of their stability and ability to bind to the top sediment layer. Filamentous mats display much greater durability after surfacing. They can, as shown in other lakes (Hillebrand 1983; Wetzel 1996; Geddes 1997), float on the water surface and grow for several days or even weeks, often sinking at the shore. They owe their durability and resistance to waves to long, tangled algae thalli. In contrast, mats built mainly of diatoms were short-lived and, depending on weather conditions, degraded fairly quickly, often releasing transported remains far from the shore, near the center of the reservoir. They are bound mostly by viscous polymeric substances secreted by diatoms (Decho 2000), which means that diatomaceous mats have a great ability to bind sediments into their matrix, incorporating as much as $3-4 \mathrm{~mm}$ of sediment. The ability to bind together particles of deposit is important for its stabilisation (Madsen et al. 1993), but may also cause bioturbation in the case of detachment of such mats from the bottom. Compared to diatoms, filamentous algae bind only a small amount of sediment. Their thalli are devoid of the substances capable of binding the particles and thus, in contrast to the biofilms formed by diatoms, they develop above the surface of the deposit and have little contact with it.

Differences between diatomaceous and filamentous mats with respect to binding the sediment, number of diaspores and their remains, and representation of species from individual ecological groups, suggest different influences on diaspore transport. This is also indicated by a statistically significant difference in average values of the Shannon index and the coefficient of variation for the two types of mats (Table 3). The diaspores found in filamentous mats suggest they 
are mainly from species with anemochorous seed dispersal (e.g. Asteraceae sp., Betula pendula, Cirsium sp., Epilobium sp., Eupatorium cannabinum L., Salix sp.) or taxa whose seeds or fruits float on the water surface (e.g. Carex sp., Sparganium erectum, Persicaria amphibia (L.) S.F. Gray) (Table 1). As a consequence, there is generally a large proportion of fruits from rushes, adapted to floating on the water surface (Sculthorpe 1967), whereas there is a low proportion of aquatic plant species, in terms of both presence and number, as their seeds usually sink rapidly (Table 2). Among aquatic species, besides the floating fruit of Persicaria amphibia and Potamogeton crispus L., only one nut of Batrachium sp. was found, which is capable of floating on the water surface for a few days (Thompson 2005), and one oospore of Chara sp. (Table 2). A very high proportion of Betula pendula fruit (401 items), dominant among trees, and indeed all counted diaspores, was a consequence of the high number of individuals around the reservoir, which produced enormous numbers of light diaspores that float on the water. Dominance of remains from seeds and fruits that likely float on the water surface, and a lack of sediment particles brought up from the bottom, suggests that filamentous algae mats are primarily responsible for transport of diaspores. This is confirmed by the generally very good preservation of most diaspores and their location on the mat surface, which indicates they were deposited during the current growing season, and not deposited in the sediment long before. Filamentous mats also have smaller Shannon index values and a greater coefficient of variation (Table 3), which may be linked to a lack of binding of older seeds and fruits in the sediment, mainly those that sink quickly. In the mats of filamentous algae, most remains were usually on the edges of a floating "raft," suggesting that these mats capture drifting diaspores while they move across the water surface. By contrast, when they sink, they may trap and concentrate the remains, which affects the abundance and species composition of the taphocoenoses formed in the sediment. It was also observed that in the vicinity of fruit-bearing plants, filamentous mats may capture and transport falling diaspores that are unable to float on the water. This is indicated by the 27 seeds of Juncus sp. found in a single sample and seven seeds of Mentha sp. found in another. Thus, such mats may contribute to the transport of quickly sinking seeds and fruits over long distances, resulting in their concentration in a small area. It is generally assumed that such diaspores normally sink in the vicinity of the parent plants, thereby indicating well their positions, but diaspore transport by mats may complicate interpretation of the remains. This may be a problem for paleobotanical reconstruction, as well as for the use of carpological remains to reconstruct past lake level changes (Hannon and Gaillard 1997).

Similar to the situation for filamentous mats, remains in diatomaceous mats were strongly dominated by fruits of $B$. pendula, with high numbers of remains in both younger, uppermost sediments (Szymczyk 2012) and older, deeper deposits (Tobolski 2000). A significant proportion of diaspore specimens found in these mats showed signs of damage, indicating they had probably been deposited on the bottom of the water body during previous growing seasons. Along with better representing plant communities dominated by species with quickly sinking diaspores, diatomaceous mats generally possess a larger number of identified remains that were previously deposited in the sediment. This is confirmed by a higher average Shannon index value and lower coefficient of variation (Table 3) than in filamentous mats. Thus, I conclude that diatomaceous mats play a greater role in the redeposition of macro-remains found in the sediment, than in the primary transport of diaspores. Their importance with respect to transport of diaspores taken from the sediments is also indicated by the amount of carpological remains, particularly those of aquatic plants, which reflects well their role in the development of modern phytocoenoses, as was also seen in topmost sediments of Lake Sławków (Szymczyk 2012).

After fruits of Betula pendula, the most numerous diaspores in diatomaceous mats were mainly small, quickly sinking seeds of Juncus sp. and Mentha sp. (Table 1). Sediments of other reservoirs also possess evidence of dispersal of seeds of these species away from parent plants (Szymczyk 2012). Similar behaviour is also observed in the case of small oospores of Chara sp. (Zhao et al. 2006). This study indicates that dispersal, especially of small, quickly sinking diaspores, may be influenced by diatomaceous mats, which are involved in their redeposition. The ability of diatomaceous mats to bind with the sediment and redeposit diaspores does not apply only to small, light diaspores. Generally, they dominate with respect to the total number of remains, but such mats also contain 
large diaspores, such as nuts of Carex sp. or even fruits of Sparganium emersum and S. erectum (Table 1). It is also possible that large numbers of diaspores in these types of mats could indirectly contribute to greater concentrations of macroremains in the top layers of sediments in the reservoir, than in other studied water bodies. The high numbers could reflect slower decomposition of falling diaspores, protected by the protective polymers secreted by diatoms. These substances bind the sediments, limiting their disturbance and oxygen supply for a long time. Harding and Chant (2000) attributed exceptionally good preservation of Oligocene macroremains in Lake Florissant, USA to such a mechanism.

\section{Conclusions}

Algal mats built of diatoms or filamentous algae, develop periodically in lakes and serve as "traps" for seeds and fruits. They may represent an important factor in the dispersal of diaspores of plants that grow in and around lake basins and thus may influence the formation of taphocoenoses.

Mats built mainly by filamentous algae are involved mainly in primary transport of diaspores, transferring them between the shores of the reservoir. They mainly catch drifting rush diaspores and anemochorous diaspores of trees and other terrestrial species, thereby contributing to their concentration. They may also capture and transport over long distances seeds and fruits that are prone to sinking quickly. Such remains are usually deposited in the vicinity of parent plants and serve as good location markers in paleolimnological studies.

Mats built mainly by diatoms bind the carpological remains deposited at the bottom with the sediment, and influence redeposition of such remains. Such mats can disperse the remains and transport them between the littoral zone and the central part of the reservoir. Diatom mats transport a larger amount of more diverse remains than filamentous mats. In diatom mats, as many as $41.7 \%$ of all taxa that occur in the lake basin were represented, including as many as $75.0 \%$ of the species that make up rush communities.

The transport and redeposition of carpological remains by algal mats in the studied reservoir suggests that their presence should be considered when interpreting macroremain analyses. Potential formation of algal mats in shallow lakes or bays may be indicated by environmental conditions that are favourable for them, such as high trophic state along with high water transparency, and abundant benthic diatoms in the sediment, in the absence of a clear biogenic lamination. Existence of such conditions in the past and the possible influence of algal mats on the transport of carpological remains can be explored by interdisciplinary study of sediments.

Open Access This article is distributed under the terms of the Creative Commons Attribution 4.0 International License (http:// creativecommons.org/licenses/by/4.0/), which permits unrestricted use, distribution, and reproduction in any medium, provided you give appropriate credit to the original author(s) and the source, provide a link to the Creative Commons license, and indicate if changes were made.

\section{References}

Andersson E, Nilsson C, Johansson ME (2000) Plant dispersal in boreal rivers and its relation to the diversity of riparian flora. J Biogeogr 27:1095-1106

Barrat-Segretain MH (1996) Strategies of reproduction, dispersion, and competition in river plants: a review. Vegetatio 123:13-37

Berggren G (1969) Atlas of seeds and small fruits of NorthwestEuropean plant species, part 2 Cyperaceae. Swedisch Natural Science Research Council, Stockholm

Berry H, Lembi CA (2000) Effects of temperature and irradiance on the seasonal variation of a Spirogyra (Chlorophyta) population in a Midwestern lake (U.S.A.). J Phycol 36:841-854

Birks HH (1973) Modern macrofossil assemblages in lake sediments in Minnesota. In: Birks HJB, West RG (eds) Quaternary Plant Ecology. Blackwell Scientific Publications, Oxford, pp 173-189

Birks HH (2007) Plant macrofossil introduction. In: Elias SA (ed) Encyclopedia of quaternary science, vol 3. Elsevier, Amsterdam, pp 2266-2288

Boedeltje G, Bakker JP, Bekker RM, Van Groenendael JM, Soesbergen M (2003) Plant dispersal in a lowland stream in relation to occurrence and three specific life-history traits of the species in the species pool. J Ecol 91:855-866

Borchardt MA (1996) Nutrients. In: Stevenson RJ, Bothwell ML, Lowe RL (eds) Algal ecology: Freshwater benthic ecosystems. Academic Press, San Diego, pp 184-228

Cappers RTJ, Bekker RM, Jans JEA (2006) Digitale zadenatlas van Nederland (Digital seed atlas of the Netherlands). Barkhuis Publishing and Groningen University Library, Groningen

Davidson TA, Sayer CD, Bennion H, David C, Rose N, Wade PM (2005) A 250 year comparison of historical, macrofossil and pollen records of aquatic plants in a shallow lake. Freshwater Biol 50:1671-1686 
Davis FW (1985) Historical changes in submerged macrophyte communities of Upper Chesapeake Bay. Ecology 66:981-993

Decho AW (2000) Microbial biofilms in intertidal systems: an overview. Cont Shelf Res 20:1257-1273

Dieffenbacher-Krall AC (2007) Surface samples, taphonomy, representation. In: Elias SA (ed) Encyclopedia of Quaternary Science, vol 3. Elsevier, Amsterdam, pp 2367-2374

Dieffenbacher-Krall AC, Nurse AM (2005) Late-glacial and Holocene record of lake levels of Mathews Pond and Whitehead Lake, Northern Maine, USA. J Paleolimnol 34:283-309

Geddes P (1997) Descriptive study of the vertical structure of floating algal mats in the Maple River. Cheboygan Co., University of Michigan (UMBS), MI

Fabiańska M, Szymczyk A, Chłapik M (2014) Fossil fuel compounds from fly dust in recent organic matter of southern Poland peats. Chem Erde Geochem 74:237-250

Falkowski PG, Raven JA (2007) Aquatic photosynthesis. Princeton University Press, Princeton

Frost PC, Elser JJ (2002) Effects of light and nutrients on the net accumulation and elemental composition of epilithon in boreal lakes. Freshwater Biol 47:173-183

Green AJ, Figuerola J, Sánchez MI (2002) Implications of waterbird ecology for the dispersal of aquatic organisms. Acta Oecol 23:177-189

Griffith AB, Forseth IN (2002) Primary and secondary seed dispersal of a rare, tidal wetland annual, Aeschynomene virginica. Wetlands 22:696-704

Goldsborough LG, Robinson GGC (1996) Pattern in wetlands. In: Stevenson RJ, Bothwell ML, Lowe RL (eds) Algal ecology: Freshwater benthic ecosystems. Academic Press, San Diego, pp 77-117

Guppy HB (1906) Observations of a Naturalist in the Pacific between 1896 and 1899. Macmillan, London

Hannon GE, Gaillard MJ (1997) The plant macrofossil record of past lake-level changes. J Paleolimnol 18:15-28

Harding IC, Chant LS (2000) Self-sedimented diatom mats as agents of exceptional fossil preservation in the Oligocene Florissant lake beds, Colorado, United States. Geology 28:195-198

Hillebrand H (1983) Developments and dynamics of floating clusters of filamentous algae. In: Wetzel RG (ed). Periphyton of freshwater ecosystem: Developments in Hydrobiology 17: 31-39

Hrynowiecka A, Szymczyk A (2011) The comprehensive paleobotanical studies of lacustrine-peat bog sediments from the Mazovian/Holstenian Interglacial at the site of Nowiny Żukowskie (SE Poland): preliminary study. Bulletin of Geography, Physical Geography Series 4:21-46

Irfanullah H, Moss B (2005) A filamentous green algae-dominated temperate shallow lake: variation on the theme of clear-water stable states? Arch Hydrobiol 163:25-47

Johansson MA, Nilsson C (1993) Hydrochory, population dynamics and distribution of the clonal aquatic plant $R a$ nunculus lingua. J Ecol 81:81-91

Koff T, Vandel E (2008) Spatial distribution of macrofossil assemblages in surface sediments of two small lakes in Estonia. Est J Ecol 57:5-20

Konieczna N, Kowalewski G (2009) Sukcesja jeziora Drążynek w świetle analizy osadów i szczątków makroskopowych
(Sedimentary and macrofossil records of lake succession in Lake Drążynek). Stud Lim et Tel 3:61-70

Kończak G, Trzpiot G (2002) Analizy statystyczne z arkuszem kalkulacyjnym Microsoft Excel (Statistical analyzes of the Microsoft Excel spreadsheet). Wydawnictwo Akademii Ekonomicznej, Katowice

Madsen KN, Nilsson P, Sundbäck K (1993) The influence of benthic microalgae on the stability of a subtidal sediment. J Exp Mar Biol Ecol 170:159-177

McDougal RL, Goldsborough LG, Hann BJ (1997) Responses of a prairie wetland to press and pulse additions of inorganic nitrogen and phosphorus: production by planktonic and benthic algae. Arch Hydrobiol 140:145-167

Müller-Schneider P (1983) Verbreitungsbiologie (Diasporologie) der Blütenpflanzen: 3. Aufl Veröff Geobot Inst ETH Stiftung Rübel Zürich 61:1-226

Nita M, Szymczyk A (2010) Vegetation changes in the Jezioro Lake on the background ofthe Holocene history of forests (Woźniki-Wieluń Upland). Acta Paleobot 50:119-132

Ozimek T (1990) Aspects of the ecology of a filamentous alga in a eutrophicated lake. Hydrobiologia 191:23-27

Palmer MA, Bell SL, Butterfield I (1992) A botanical classification of standing waterin Britain: applications for conservation and monitoring. Aquat Conserv 2:125-143

Rasmussen P, Anderson NJ (2005) Natural and anthropogenic forcing of aquaticmacrophyte development in a shallow Danish lake during the last 7,000 years. J Biogeogr 32:1993-2005

Ridley HN (1930) The Dispersal of Plants Throughout the World. Reeve and Co., Ltd

Rosenberg R, Elmgren R, Fleischer S, Jonsson P, Persson G, Dahlin H (1990) Marine eutrophication case studies in Sweden. Ambio 19:102-108

Santamaria L, Charalambidou I, Figuerola J, Green AJ (2002) Effect of passage through duck gut on germination of fennel pondweed seeds. Arch Hydrobiol 156:11-22

Sculthorpe CD (1967) The Biology of Aquatic Vascular Plants. Edward Arnold, London

Scheffer M (2001) Ecology of shallow lakes. Kluwer Academic Pub, Dordrecht

Shannon CE, Weaver W (1949) A mathematical theory of communication. Univiversity of Illinois Press, Urbana, pp 29-125

Sobczyk M (1994) Statystyka (Statistics). PWN, Warszawa

Szymczyk A (2012) Relations between assemblages of carpologicalremains and modern vegetation in a shallow reservoir in southern Poland. J Paleolimnol 48:503-516

Sundback K, Carlson L, Nilsson C, Jönsson B, Wulff A, Odamark A (1996) Response of benthic microbial mats to drifting green algal mats. Aquat Microb Ecol 10:195208

Sutherland TF, Amos CL, Grant J (1998) The effect of buoyant biofilms on the erodability of sublittoral sediment of a temperate microtidal estuary. Limnol Oceanogr 43:225-235

Thompson P (2005) Creative Propagation. Timber Press Inc, Cambridge

Tobolski K (2000) Przewodnik do oznaczania torfów i osadów jeziornych (The Guide for the determination of Peat and Lake Sediments). Vademecum Geobotanicum 2, PWN, Warszawa 
Usher HD, Blinn DW (1990) Influence of various exposure periods on the biomass and chlorophyll a of Cladophora glomerata (Chlorophyta). J Phycol 26:244-249

Van den Broek T, Van Diggelen R, Bobbink R (2005) Variation in seed buoyancy ofspecies in wetland ecosystems with different flooding dynamics. J Veg Sci 16:579-586

Van der Pijl L (1969) Principles of Dispersal in Higher Plants. Springer-Verlag, Berlin

Wetzel RG (1996) Benthic algae and nutrient cycling in lentic freshwater ecosystems. In: Stevenson RJ, Bothwell ML, Lowe RL (eds) Algal Ecology: Freshwater benthic ecosystems. Academic Press, San Diego, pp 641-667

Widdows J, Blauw A, Heip CHR, Herman PMJ, Lucas CH, Middelburg JJ, Schmidt S, Brinsley MD, Twisk F, Verbeek
H (2004) Role of physical and biological processes in sediment dynamics of a tidal flat in Westerschelde Estuary, SW Netherlands. Mar Ecol Prog Ser 274:41-56

Zhao Y, Sayer CD, Birks HH, Hughes M, Peglar SM (2006) Spatial representation ofaquatic vegetation by macrofossils and pollen in a small and shallow lake. J Paleolimnol 35:335-350

Zohary T, Fishbein T, Kaplan B, Pollingher U (1998) Phytoplankton-metaphyton seasonal dynamics in a newly-created subtropical wetland lake. Wetlands Ecol Manage 6:133-142 